\title{
Prenatal Development of the Pars Intermedia of the Pituitary Gland in the Water Buffalo (Bubalus bubalis).
}

\section{Hossam Attia ${ }^{a, *}$, Mohamed Alkafafy ${ }^{\text {b) }}$, Reda Rashed ${ }^{c)}$}

a) Department of Histology and Cytology, Faculty of Veterinary Medicine, Benha University, Egypt

b) Department of Cytology and Histology, Faculty of Veterinary Medicine, Minuofiya University, Sadat City Branch, Egypt

c) Department of Anatomy and Embryology, Faculty of Veterinary Medicine, Minuofiya University, Sadat City Branch, Egypt

\section{Abstract}

This study was carried out on pituitary glands collected from buffalo embryos and fetuses with a crown vertebral rump length (CVRL) ranging from 1.5 to 95 $\mathrm{cm}$. The specimens were immediately immer-sed in the fixatives at least 3 days and paraffin embedded for routine histological work. The primordia of the pars intermedia $(\mathrm{PI})$ appeared at $1.5 \mathrm{~cm}$ CVRL as group of undiffere-ntiated mesenchymal cellular band. This band was completely enclosing the pars nervosa (PN) at $3.2 \mathrm{~cm}$ CVRL. It appeared thick ventrally around the bottom of the PN. It was separated from the pars distalis (PD) via the hypophyseal cleft and from the neural lobe via thick reticular connective tissue fibers. These cells were differentiated to chromophils and chromophobes at 24 $\mathrm{cm}$ CVRL. The chromophils were exclusively basophils. Melanotrophs (MSH-cells) began to appear as polyhedral cells; seen scattered among the follicular cells at $35 \mathrm{~cm}$ CVRL. Adrenocorticotrophs (ACTH-cells) first

J. Vet. Anat. appeared at $75 \mathrm{~cm}$ CVRL. The numbers of $\mathrm{MSH}-$ and ACTH-cells increased toward the full term age. In conclusion, this numerical increase might prepare the foetal adrenals to face the stresses during and after parturition; and the foetal skin to protect itself (by melanin) from the solar insults.

\section{Key words}

Pituitary gland, Water buffalo, Pars intermedia, Prenatal development

\section{Introduction}

The pars intermedia (PI), as one of the three compartments of the pituitary gland (Dellmann, 1998; Dorton, 2000), exists during developmental stages in most vertebrates including the human fetus. In the adult human, the PI is no longer identifiable as a distinct layer (Dellmann, 1998). However, isolated groups of such cells can be found invading a short distance in the pars nervosa (PN). On the other hand, it is large especially in the camel and llama (Martin, 1976).

Vol 3 No 1, (2010) 43 - 54 
The PI lies adjacent to the neural lobe; from which it is incompletely separated by a thin layer of connec-tive tissue (CT), while it is separated from the PD by the hypophyseal cleft (Dianne et al., 2006) or cavum which is usually filled with colloid material (Perry et al., 1981; Prasad and Singh, 1980). However, it was reported that the $P D$ is being separated from the PI by a narrow band of CT, which is intermittently broken with vesicles of different sizes (Salama and Deeb, 1975). The PI contains three types of cells: basophils, chromophobes, and cells forming the colloidfilled cysts (Perry et al., 1981). These cysts are the remnants of Rathke's pouch.

The development of PI was extensively studied in fishes (Amano et al., 2005 ; Einarsdóttir et al., 2006), amphibians (Heer et al., 2009; Kawamura and Kikuyama, 1998), reptiles (Batista et al., 1989; Ferran-dino and Grimaldi, 2004), rodents (Boer et al., 1980; Dupouy and Dubois , 1975; Eurenius and Darskar, 1975; Negm, 1970; Wilson and Morgan 1980), rabbit (Chatterjee, 1976),dog (Sasaki and Nishioka 1998), sheep (Liggins, 1968; Silman et al., 1979) pig (Sasaki et al., 1992), camel (ElGharbawy, 1990) and human (Dubois, 1973, Solov'ev et al., 2008).

Little information is available about the development of the $\mathrm{PI}$ in the water buffalo. Thus, in a continuing study of the ontogeny of the pituitary gland in the buffalo (Attia, 2008), the present study aimed to shed light on the prenatal development of the $\mathrm{PI}$ in this economically important species.

\section{Materials and methods}

The pituitary glands of 70 buffalo embryos and fetuses with their CVRL ranging from 1.5 to $95 \mathrm{~cm}$ were collected from many aba-ttoirs in Cairo, kalyobia and Giza Governorates. The embryos and fetuses were freed from their embryonic membranes just after collection and carefully examined for exclusion of any abnormalities. While the embryos with CVRL ranged from I to $6 \mathrm{~cm}$ were taken as a whole to the fixatives, the heads from fetuses with CVRL ranged from 7 to $95 \mathrm{~cm}$ were cut and opened and the pituitary glands were carefully removed and immediately immersed in the fixatives. Different fixatives were used; Susa, Bouin's and Neutral buffered formalin. The specimens were dehydrated, cleared, embedded in paraffin and sagittaly sectioned. The specimens were stained with general, special and histochemical stains. These included Harris haematoxylin, Lead haematoxylin, Crossman's tri-chrome stain, Gomori reticulin method, Periodic acid Schiff, Alcian blue, Alcian blue/ PAS, Acid fuchsin aniline blue, Bromin-Alcian blueOrange G-Fuchsin (BR-AB-OFG) method and Peracetic acid Alcian blue PAS orange $G$ method ( PA-AB-PASOG ). These methods were after Bancroft et al., (1994).

The adrenocorticotrophs (ACTH-cells) and melanotrophs (MSH-cells) were counted in 5 different tissue sections for each age (35-95 cm CVRL) group. For each section, cells were counted in 10 fields (x10) and the mean value for each section was calculated. The 
numbers (means $\pm \mathrm{SD})^{1}$ of cells were then calculated for each age group (table 1). Photomicrographs of the PI were captured and processed by an image processing program.

\section{Results}

The primordia of the PI appeared as early as at $1.5 \mathrm{~cm}$ CVRL as an evagination from the stomatodoeum (Rathk's pouch) represented by group of undifferentiated mesenchymal cells (Fig 1a). A pronounced cellular proliferation was more evident in the posterior wall of Rathk's pouch than in its other regions. The cells increased in size and the PI appeared as a thin band surrounding the PN (Fig 1b). The blood vessels and the fine collagen fibres began to appear at the margin between $\mathrm{PN}$ and $\mathrm{PI}$ and separate the PI from the architecture of the PN (Fig 1b). These cells were characterized by deeply stained cytoplasm and large central nuclei. Some cells appeared with irregular outline. The nuclei were spherical with peripheral condensed chro-matin granules and a prominent nucleolus. Other cells contained more nucleoli at $4.5 \mathrm{~cm}$ CVRL. These cells were located underneath the epithelium of the hypophyseal cleft. Mitotic figures were prominent at this stage (Fig 1c). The cells lining the hypophyseal cleft start to differentiate to columnar epithelium (Fig 1d).

\footnotetext{
1 Microsot_Excel 2003 program
}

At 14-18 cm CVRL, the undifferentiated cells of the $\mathrm{PI}$ increased in size and number.

These cells were arranged in the form of short cords or single cells with granular acidophilic cytoplasm (Fig 1e). The staining intensity of these cells was less than the neighbouring cells in PN.

At $24 \mathrm{~cm}$ CVRL, two types of cells were observed in the $\mathrm{PI}$, chromophils and chromophobes. Chromophils were only basophilic with oval to ovoid centrally located nuclei. These cells were arranged perpen-dicular to the cleft in the form of light and dark islands of cells (Fig 1f).

At $30-50 \mathrm{~cm}$ CVRL, The cells of the PI were arranged in the form of irregular anastomosing cords or follicles surrounded by CT. Polyhedral cells with oval or spherical, centrally located nuclei and slightly basophilic cytoplasm were seen among the follicular cells represent-ting the melanotrophs (Fig 2a). Chromophobes were spherical or oval cells scattered along with the basophilic cells in the follicles with unstained cytoplasm and vesicular eccentric nuclei (Fig 2b).

At $60-80 \mathrm{~cm}$ CVRL, the melanotrophs increased in number and size and appeared in the form of collected groups or follicles (Fig 2c). The follicles separated from each others by CT septa that seem to divide the PI into incomplete compartments (Fig 2d, 3c). Tall columnar cells with oval nuclei and granular cytoplasm were appeared at $75 \mathrm{~cm}$ CVRL that represent the ACTH 
cells (Fig 2e, 3a). These cells were concentrated in the parts of the PI next to the PN and stained dark blue or black with lead haematoxylin. Thick CT fibers separated the PN from the PI (Fig $2 f, 3 c)$.

At $90-95 \mathrm{~cm}$ CVRL, the PI appeared as thin band of tissue completely surrounding the PN. It appeared thick at the parts that surround the bottom of the PN. Blood capillaries were rarely distributed among the follicles while it appeared numerous at the junction between the PN and PI (Fig 2f). The cells of the PI appeared oval, columnar or polygonal in shape with large centrally located nuclei and prominent one or two nucleoli (Fig 3b). Melanotrophs appeared as large polyhedral cells that were distributed among the follicles (Fig 3b). The cells of the PI showed variable PAS reactivity (Fig 3d). The ACTH and MSH cells represented the bulk cells of the PI while the chromophobes represent-ted the less frequent cell type. The numbers of adrenocorticotrophs \& melanotrophs increased toward the full term age (table 1). A structureless homogenous mass (colloid) was located in the center of the follicles especially in full term fetuses (Fig $3 e$, 3f).

\section{Discussion}

The primordia of the $\mathrm{PI}$ appeared at 1.5 $\mathrm{cm}$ CVRL as evagination from the stomatodoeum in the form of undifferentiated mesenchymal cells. The current study was in accord with previous works recorded in buffalo (Wahba,
1985), in camel (El-Gharbawy, 1990) and in rat (Negm, 1970). PI of water buffalo enclosed the PN completely from all sides. This observation goes in line with that described by Salama and Deeb (1975), Prasad and Singh (1980) and Wahba, (1985) in the buffalo and Paino et al., (1981) in cattle. Similar findings were also described in other mammals as in musk shrew (Naik and Dominic, 1972). In the sheep the PI appeared as a compact, incompletely lobulated $\mathrm{V}$-shaped region confined between $P D$ and $P N$, and is closely associated with the PN (Perry et al., 1981).

The PI was separated from the PD by a prominent epithelium-lined, amorphous material-containing hypophyseal cleft. In areas where the cleft space was absent, the junction between the $\mathrm{PI}$ and PD was not clearly defined. Similar observations were reported by Jubb and McEntee (1955); Salama and Deeb (1975) and Prasad and Singh (1980), but it differed in other mammals as in musk shrew, in which the hypophyseal cleft separated the PI from the PN anteriorly and ventrally (Naik and Dominic, 1972).

Moriarty and Moriarty (1973) obser-ved the ACTH- and $\mathrm{MSH}$-cells in the rat intermediate lobe by using the peroxidase-antiperoxidase complexunlabeled antibody technique. MSHcells are most abundant in all domestic mammalian species (Dell-mann, 1998). The $\mathrm{PI}$ produces $\mathrm{MSH}$, which causes the expansion of melanocytes in amphibian and possibly stimulates the melanocytes in mammals (Dellmann, 
1998). In the present study, the melanotrophs firstly appeared at $35 \mathrm{~cm}$ CVRL while the adrenocorticotrophs appeared at a later stage $(75 \mathrm{~cm}$ CVRL).

Although the region of the CT septum confined between the $\mathrm{PI}$ and the $\mathrm{PN}$ is richly vascularized, blood vessels were rarely observed in the $\mathrm{PI}$. It is presumed that the $\mathrm{PI}$ is adequately nourished by diffusion from these nearby vessels (Howe and Maxwell, 1968). It is worth noted that the fenestrated blood vessels were not observed in the rabbit $\mathrm{PI}$ until five months after birth (Chatterjee, 1976).

The parenchyma of the PI was entirely devoid of acidophils. It consisted mainly of two types namely, basophils and chromophobes. The latter cells are small and have small mostly spherical nuclei (Salama and Deeb, 1975 and Wahba, 1985). On the other hand ElGharbawy, (1990) reported acidophils located among the follicles near the hypophyseal cleft.

The basophilic cells were cuboidal or columnar cells arranged in groups with small patches of colloid present in the lumen. Their nuclei were oval to spherical and some of them have a very irregular outline. Similar findings were reported in ruminant (Perry et al., 1981; Wahba, 1985; Dellmann 1998).

The cells of the developing PI attained an alveolar appearance and were light stained. They conferred the $\mathrm{PI}$ an appearance of alternating dark and light areas. These results were supported by

the findings of Wahba (1985) in the buffalo and El-Gharbawy (1990) in the camel.

In the rat $\mathrm{PI}, \mathrm{ACTH}$-cells and the $\alpha$ MSH-cells first appeared on $18^{\text {th }}$ gestational day while the $\beta-\mathrm{MSH}$ cells appeared on $17^{\text {th }}$ gestational day (Dupouy and Dubois, 1975). Thus, it is noticeable that ACTH-cells appear in late pregnancy. Likewise, ACTH-cells were observed in the fetal porcine PD and $\mathrm{PI}$ at 40 days of gestation (Sasaki et al., 1992). In human, during the first half of pregnancy, some cells are easily recognizable owing to their cellular organelles. These cells may be responsible for the $\mathrm{MSH}$ secretion of human fetal anterior hypophysis (Dubois, 1973).

The cells of PI displayed a basophilic staining affinity. Similar findings were reported by Salama and Deeb (1975); Prasad and Singh (1980) and Wahba (1985). These cells have variable affinities for the PAS reaction. Therefore, whereas some cells took deeper stain the other some displayed a lighter staining with PAS/OG procedure. This was in agreement with the observation of Prasad and Singh (1980).

The present findings showed that the PI was well differentiated and exhibited relatively high ratios of adrenocorticotrophs in the last trimester of gestation. This supports the possibility that the fetal PI may play a role in the initiation of parturition (Liggins et al. 1967). Additionally, the parturition can be induced within a few days following 
synthetic corticotropin infusion into the intact (Liggins 1968) or hypophysectomized (Jones et al. 1978) fetus.

In conclusion, the numbers of the MSHand $\mathrm{ACTH}$-cells increased toward the full term age. These cells represented the majority of cells of the PI while the chromophobes represented the less frequent cell type. It is worth noting that the increase in melanotrophs' numbers is simultaneous with the change in the skin and hair color in the full term calves through its effect on melanocytes, while the increased numbers of adrenocorticotrophs set up the adrenals of the newborn animals for facing the potential stresses during and after parturition.

\section{References}

Amano M, Takahashi A, Yamanome T, Oka Y, Amiya N, Kawauchi H, Yamamori K (2005): Immunocytochemical localization and ontogenic development of alpha-melanocyte-stimulating hormone (alpha-MSH) in the brain of a pleuranectiform fish, barfin flounder. Cell Tissue Res., 320(1):127-34.

Attia HF (2008): Histogenesis of the pars nervosa in buffalo. $\mathrm{J}$ Vet. Anat., 1(1):22-8.

Bancroft J D, Cook HC, Stirling RW, Turner DR (1994): Manual of Histological Techniques and their diagnostic applications , $2^{\text {nd }}$ ed. Churchill Living-stone , Edinburgh, London.

Batista MA, Doerr-Schott J, Bello AR (1989): Immunohisto-chemical study on the development of the adeno-hypophysial cells in the lizard Gallotia galloti. Anat Embryol (Berl), 180 (2):143-9.

Boer K, Dogterom O, Pronker HF (1980): Pituitary content of oxytocin, vasopressin and $\alpha$ Melanocyte-stimulating hormone in the fetus of the rat during labour. 3. Endocr., 86: 221-229.

Chatterjee P (1976): Development and cytodifferentiation of the rabbit pars intermedia. II. Neonatal to adult. J Anat., 122: 415-433.

Dellman HD (1998): Endocrine system. In: Textbook of Veterinary Histology. Chapt. 15, $5^{\text {th }}$ Edition, (Eds H D Dellmann and J Eurell , Williams and Wilkins). pp 287-302.

Dianne McFarlane, Jill Beech, Alastair Cribb (2006): Alpha-melanocyte stimulating hormone release in response to thyrotropin releasing hormone in healthy horses, horses with pituitary pars intermedia dysfunction and equine pars intermedia explants. Domestic Animal Endocrinol., 30(4): 276-288.

Dorton AM (2000): The pituitary gland: embryology, phys-iology, and pathophysio-logy. Neonatal Netw., 19(2): 9-17.

Dubois $P$ (1973): The cells responsible for the secretion of $\mathrm{MSH}$ in the human fetal antehypophysis. Bull. Assoc. Anat., 57 (156): 7782.

Dupouy OP, Dubois MP (1975): Ontogenesis of the alpha-MSH, beta-MSH and ACTH cells in the foetal hypophysis of the rat. Correlation with the growth of the adrenals and adrenocortical activity. Cell Tiss. Res., 161(3): 373-384. 
Einarsdóttir IE, Silva N, Power DM, Smáradóttir $\mathrm{H}$, Björnsson BT (2006): Thyroid and pituitary gland development from hatching through metamorphosis of a teleost flatfish, the Atlantic halibut. Anat Embryol (Berl), 211(1):47-60.

El-Gharbawy S M (1990):

Developmental studies of the adenohypophysis of the one humped camel (Camelus dromedarius). A PhD thesis. Cairo University.

Eurenius L, Darskar R (1975): Electron microscope studies on the intermediate lobe of the embryonic mouse. Cell Tiss. Res., 164: 11-26.

Ferrandino I, Grimaldi MC (2004): Immunohistochemical study of adenohypophysial cells during embryonic develop-ment in the reptile Chalcides chalcides (Squamata, Scin-cidae). J Mol Histol., 35(1): 55-61.

Heer T, Pozzi AG, Yovanovich CA, Paz DA (2009): Distribution pattern of neuropeptide $Y$ in the brain, pituitary and olfac-tory system during the larval development of the toad Rhinella arenarum (Am-phibia: Anura). Anat Histol Embryol., 38(2):89-95.

Howe A, Maxwell DS (1968): Electron microscopy of the pars intermedia of the pituitary gland in rat. Gen Comp Endocrinol., 11: $169-185$.

Jones CT, Kendall JZ, Ritchie JWK, Robinson JS, Thorburn GD (1978): Adrenocorticotrophin and corlicosteroid changes during dexamethasone infusion to intact and Synacthen infusion to hypo-physectomized foetuses. Acta Endocrinol (Kbh), 87:203-211.
Jubb KV, McEntee K (1955): Observations on the bovine pituitary gland. II. Architec-ture and cytology with special reference to basophil cell function. Cornell Vet., 45: 593641.

Kawamura K, Kikuyama S (1998): Morphogenesis of the hypothalamus and hypophysis: their association, dissocia-tion and reassociation before and after "Rathke". Arch Histol Cytol., 61(3):189-198.

Liggins GC (1968): Premature parturition after infusion of corticotrophin or cortisol into foetal lambs. J Endocrinol., 42: 323-329.

Liggins GC, Kennedy PC, Holm LW (1967): Failure of initiation of parturition after electrocoagulation of the pituitary of the fetal lamb. Am J Obstet Gynecol., 98: 1080-1086.

Martin CR (1976): The pituitary gland: In Textbook of endo-crine physiology $1^{\text {st }}$ ed. The Williams \& Wilkins. Com-pany Baltimore.

Moriarty GC, Moriarty C M (1973): Ultrastructural localization of $\mathrm{ACTH}$ and $\mathrm{MSH}$ in rat and human pituitaries. Anat. Rec., 175: 393.

Naik DR, Dominic CJ (1972): The pituitary gland of the musk shrew a Suncus murinus $\mathrm{L}$. (Insectivora), with special reference to the cytology of the adenohypophysis. Am. J. Anat., 134: 145-165.

Negm IM (1970): Development of the intermediate lobe of the rat pituitary and differen-tiation of its cells. Acta Anat., 77: 422437.

Paino G, Langella M, Caputo G (1981): Vascular feature of the 
hypophysis in Bubalus buffalus

. Acta Anat., 110: 206-218.

Perry RA, Robinson PM, Ryan GB (1981): Ultrastructure of the pars intermedia of the adult sheep hypophysis. Cell Tiss. Res., 217: 211-223.

Prasad G, Singh LP (1980): Histological and certain histochemical studies on the adenohypophysis of the non pregnant Indian buffalo (Bubalus bubalis). Indian J. Anim. Sci., 50 (9): 710-717.

Salama A, Deeb S (1975): The pituitary gland of Buffalo-Cow: A histomorphological study. J. Egypt. Vet. Med. Assoc., 35 (2): 5-14.

Sasaki F, Ichikawa Y, Yamauchi S (1992): Immunohistological analysis in the distribution of cells in the fetal porcine adenohypophysis. Anat Rec. , 233 (1):135-42.

Sasaki F, Nishioka S (1998): Fetal development of the pituitary gland in the beagle. Anat Rec, 251(2): 143-51.

Silman RE, Holland D, Chard T, Lowry PJ, Hope J, Rees LH, Thomas A, Nathanielsz P (1979): Adrenocorticotro-phin-related peptides in adult and foetal sheep pituitary glands. J Endocrinol., 81: 19-34.

Solov'ev GS, Bogdanov AV, Panteleev SM, Yanin VL (2008): Embryonic mor-phogenesis of the human pituitary. Neurosci Beh Physiol., 38(8): 829-33.

Wahba TM (1985): Studies on the function of pituitary gland of Egyptian water buffalo at various stages of developpment. M. Sc. Thesis. Cairo Univ.

Wilson BF, Morgan MA (1980): Levels of K-Melanotrophin in the plasma and pituitary glands of fetal and juvenile rats and in the plasma of adult female rats during pregnancy and lactation. J. Endocrinol., 84: 363 - 370. 
Development of Pars intermedia in pituitary of water buffalo Attia et al.

Table(1): Numerical values (means \pm SD) of melanotrophs and adreno- corticotrophs.

\begin{tabular}{|l|l|l|l|}
\hline CVRL (cm) & MSH cells & CVRL (cm) & ACTH cells \\
\hline $\mathbf{3 5}$ & $11.6 \pm 1.25$ & $\mathbf{7 5}$ & $9.2 \pm 1.30$ \\
\hline $\mathbf{4 5}$ & $16.4 \pm 1.14$ & $\mathbf{7 8}$ & $15.6 \pm 1.29$ \\
\hline $\mathbf{5 5}$ & $22.2 \pm 2.16$ & $\mathbf{8 1}$ & $19.8 \pm 1.64$ \\
\hline $\mathbf{6 5}$ & $31.4 \pm 1.95$ & $\mathbf{8 4}$ & $24.0 \pm 2.45$ \\
\hline $\mathbf{7 5}$ & $37.0 \pm 1.58$ & $\mathbf{8 7}$ & $29.6 \pm 1.95$ \\
\hline $\mathbf{8 5}$ & $41.8 \pm 1.48$ & $\mathbf{9 0}$ & $36.0 \pm 1.87$ \\
\hline $\mathbf{9 5}$ & $49.4 \pm 2.60$ & $\mathbf{9 5}$ & $41.6 \pm 1.82$ \\
\hline
\end{tabular}



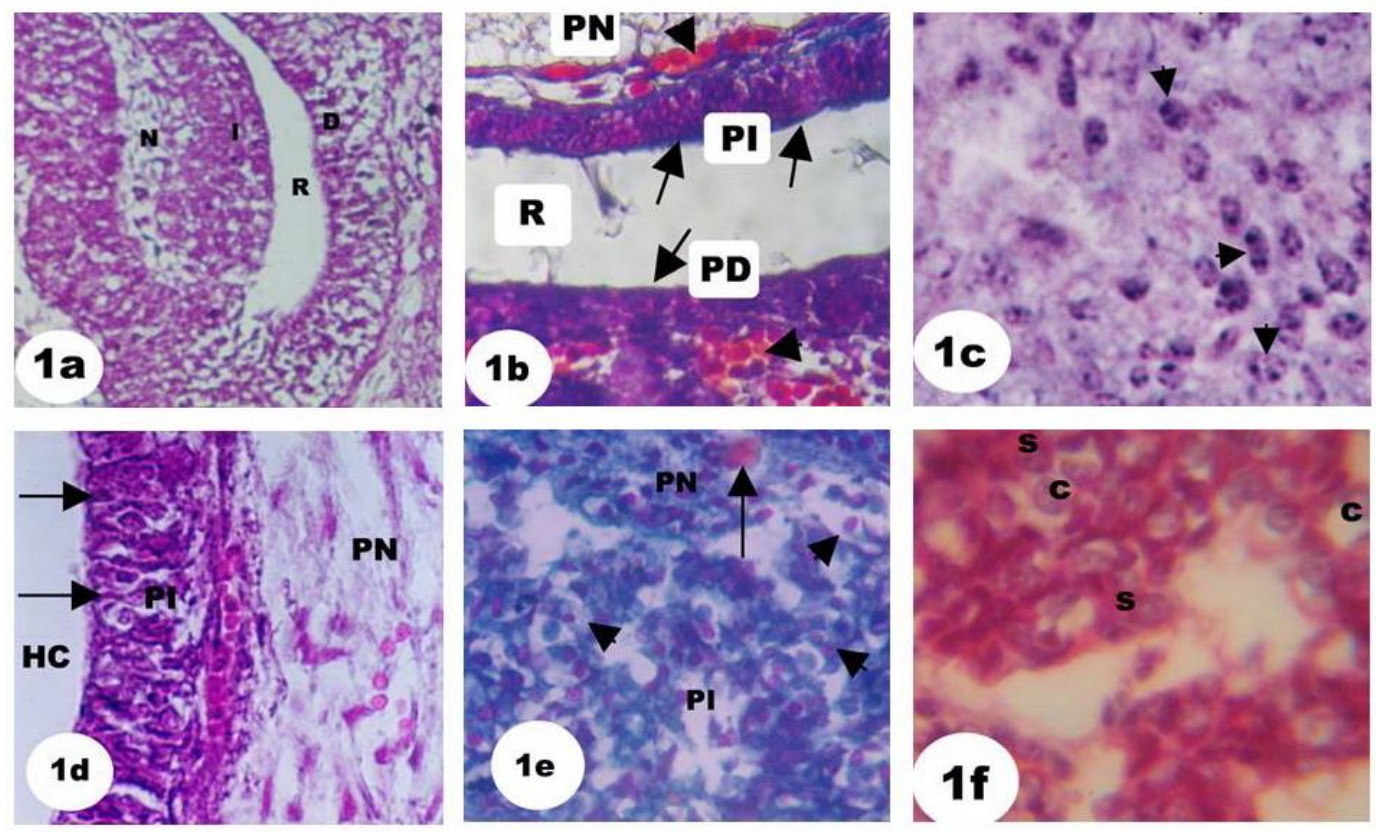

\section{Fig (1)}

(a) Pituitary gland, buffalo, H\&E; $1.5 \mathrm{~cm} \mathrm{CVRL,} \mathrm{showing} \mathrm{the} \mathrm{primordial} \mathrm{of} \mathrm{the} \mathrm{pars}$ nervosa $(N)$ and pars intermedia (I) separated from the pars distalis (D) by Rathke's pouch (R). X40

(b) Pituitary gland, buffalo, Crossmon's trichrome; $3 \mathrm{~cm} \mathrm{CVRL.} \mathrm{Pars} \mathrm{nervosa} \mathrm{(PN)} \mathrm{and}$ intermedia (PI) separated from pars distalis (PD) by Rathke's pouch (R); developing blood vessels (arrowheads). X40

(c) Pituitary gland, buffalo, H\&E; $4.5 \mathrm{~cm}$ CVRL; deeply stained cells with mitotic figures (arrowheads). X20

(d) Pituitary gland, buffalo, BR-AB-OFG; $6 \mathrm{~cm}$ CVRL, the columnar cells (arrows) of the hypophyseal cleft (HC), pars intermedia (PI), pars nervosa (PN). X20

(e) Pituitary gland, buffalo, OFG, $18 \mathrm{~cm} \mathrm{CVRL,} \mathrm{cells} \mathrm{arranged} \mathrm{in} \mathrm{short} \mathrm{cords}$ (arrowheads) in pars intermedia (PI), pars nervosa (PN), blood vessel (arrow). X10

(f) Pituitary gland, buffalo, H\&E; $24 \mathrm{~cm} \mathrm{CVRL,} \mathrm{the} \mathrm{differentiated} \mathrm{cells:} \mathrm{chromophobes} \mathrm{(c)}$ and chromophils (s). X4 

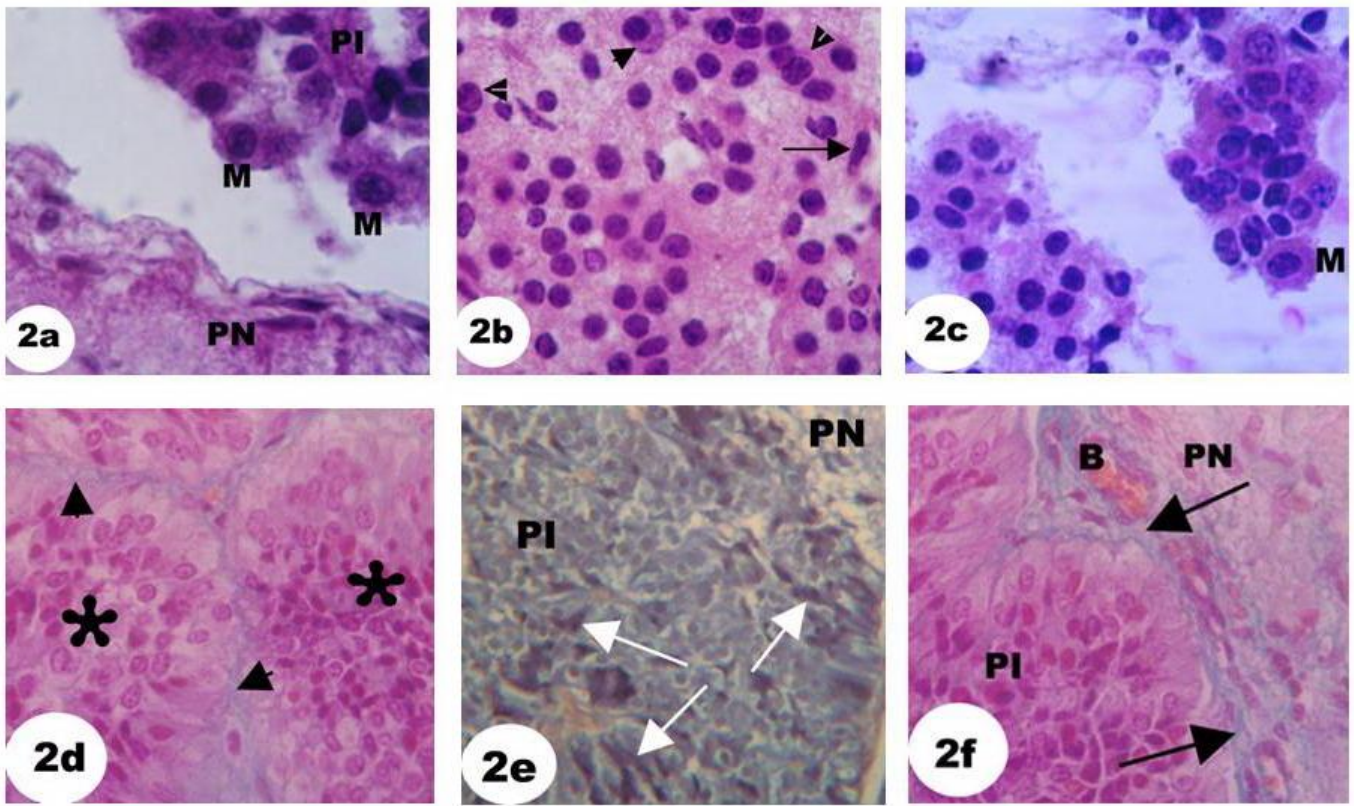

Fig (2)

(a) Pituitary gland, buffalo, H\&E, $35 \mathrm{~cm}$ CVRL, the polyhedral melanotrophs (M) in pars intermedia (PI), pars nervosa (PN). X40

(b) Pituitary gland, buffalo, H\&E, $50 \mathrm{~cm}$ CVRL, the different forms of the PI cells. Chromophobes (arrow), melanotrophs (arrowheads),.X20

(c) Pars intermedia, buffalo, H\&E, $62 \mathrm{~cm}$ CVRL, the increased size of melanotrophs (M). X40

(d) Pituitary gland, buffalo, Crossmon's trichrome, $70 \mathrm{~cm}$ CVRL, the incomplete compartements (asterisks) of the PI, separated by thin CT septa (arrowheads). X40

(e) Pituitary gland, buffalo, Lead haematoxylin, $75 \mathrm{~cm}$ CVRL, pars nervosa (PN), the adrenocorticotrophs (arrows) of pars intermedia (PI). X40

(f) Pituitary gland, buffalo, Crossmon's trichrome, $80 \mathrm{~cm}$ CVRL, blood capillaries (B) in the CT septum (arrows) separating pars intermedia (PI) from pars nervosa (PN). X100 

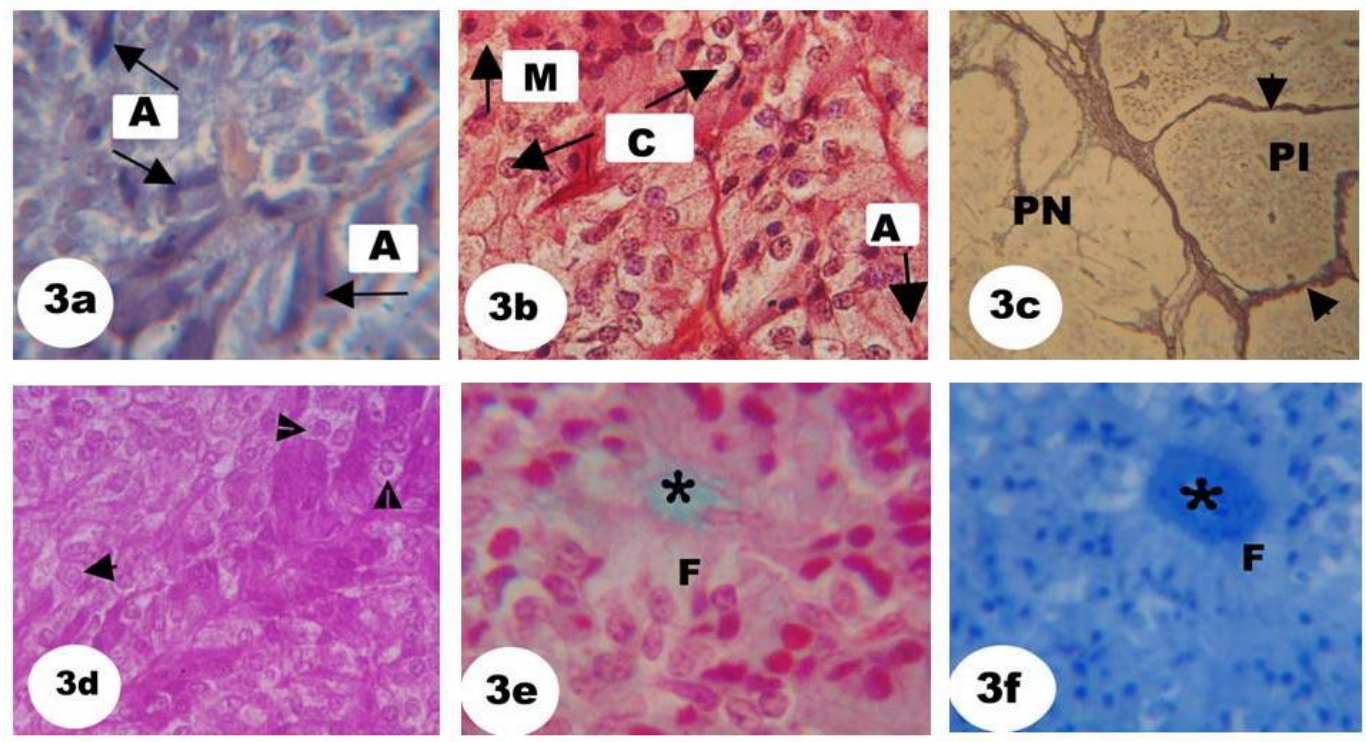

\section{Fig (3)}

(a) Pituitary gland, buffalo, Lead haematoxylin, $91 \mathrm{~cm} \mathrm{CVRL}$, the adrenocorticotrophs (A). X100

(b) Pituitary gland, buffalo, PA-AB-PAS-OG, $90 \mathrm{~cm}$ CVRL, the arrangement of the adrenocorticotrophs ( $A$ ), melanotrophs ( $M$ ) and chromophobes ( c ). X40

(c) Pituitary gland, buffalo, Gomori reticulin, $93 \mathrm{~cm}$ CVRL, pars nervosa (PN); the stroma of the pars intermedia (PI), represented by thin reticular partitions (arrowheads). X40

(d) Pars intermedia, buffalo, PAS, $95 \mathrm{~cm}$ CVRL, variable PAS reactivity in the different PI cells: melanotrophs (arrowheads) and chromophobes (notched arrowheads). X40

(e) Pituitary gland, buffalo, BR-AB-OFG, $95 \mathrm{~cm}$ CVRL, the colloid materials (asterisk) in the follicle $(F)$. X40

(f) Pars intermedia, buffalo, Toludine blue, $95 \mathrm{~cm} \mathrm{CVRL,} \mathrm{the} \mathrm{colloid} \mathrm{materials} \mathrm{(asterisk)}$ in the follicle $(F)$ and different cell types. X100 